\title{
BEAUTY AND METAPHYSICS
}

\author{
WILLIAM HASKER
}

Huntington University

\begin{abstract}
It is shown through examples ranging from Parmenides and Plato to Whitehead and Wittgenstein that beauty is central among the values that have made metaphysical theories appealing and credible. A common attitude would be that the aesthetic properties of metaphysical theories may be important for effective presentation but are irrelevant to the cognitive value of the theories. This however is question-begging, since it assumes without argument that ultimate reality is indifferent to value-considerations such as beauty. If on the contrary we allow that the aesthetic properties of theories may be cognitively relevant, which such properties should be considered? This question is explored in the final section of the paper.
\end{abstract}

The title of this essay is "Beauty and Metaphysics." This may remind some of you of another, more famous, title: "Beauty and the Beast." My hope, though, is that even those readers who regard metaphysics as beastly will be in favor of beauty, and so I will have at least a halfway chance of gaining your interest and approval. My thesis is that beauty is intimately involved in metaphysics, to the extent that beauty is central among the values that have made metaphysical theories appealing and credible. I will not claim that all metaphysicians have been deeply concerned about the beauty of their results; that would not be the case. Bertrand Russell, for instance, once wrote that "the point of philosophy is to begin with something so simple as not to seem worth stating, and to end with something so paradoxical that no one will believe it." 1 It would be rash to deny that Russell achieved this goal in some of his own philosophical endeavors! And on the other hand, beauty by itself is by no means a guarantee of metaphysical excellence. When Keats wrote, "Beauty is truth, truth beauty,"

${ }^{1}$ Bertrand Russell, ,The Philosophy of Logical Atomism, Lecture II, “ in Readings in Twentieth-Century Philosophy, ed. William P. Alston and George Nakhnikian (London: The Free Press, 1963), 310.

European Journal for Philosophy of Religion i (2009), Pp. 65-76 
he neatly provided his own counterexample: his assertion is undeniably beautiful, but it is equally certain that it is not true.

Beauty, then, is not sufficient for success in metaphysics, and perhaps it is not necessary either. Nevertheless, I maintain that it has been, and continues to be, an important ingredient in the construction and reception of metaphysical theories. I shall illustrate this thesis with a few examples, drawn from the history of philosophy, among many others that could be adduced. We begin with the very founder of the metaphysical enterprise, Parmenides. Probably most of us have wondered, at one time or another, how Parmenides found it possible to believe in his own theory-a theory that outrages common sense and ordinary experience by denying the very existence of motion, change, and a plurality of objects in the world. To be sure, Parmenides offered arguments for his conclusion, and these arguments were later reinforced by those of his disciple Zeno. To many of us, though, the arguments seem insufficient; one may be puzzled by the paradoxes that are put forward, but they don't seem to provide sufficient motivation for the even more paradoxical conclusion we are asked to accept. My proposal is that Parmenides was enthralled by what was for him the overwhelming beauty of the conception of Being he had arrived at, a conception partially conveyed in the following lines:

But motionless in the limits of mighty bonds, it is without beginning or end, since coming into being and passing away have been driven far off, cast out by true belief. Remaining the same, and in the same place, it lies in itself, and so abides firmly where it is. For strong Necessity holds it in the bonds of the limit, which shuts it in on every side, because it is not right for what is to be incomplete. For it is not in need of anything, but not-being would stand in need of everything... But since there is a furthest limit, it is complete on every side, like the body of a well-rounded sphere, evenly balanced in every direction from the middle; for it cannot be any greater or any less in one place than in another. ${ }^{2}$

Whether this description will strike you as compellingly beautiful I cannot say; probably different minds will have differing responses. But I believe it did strike Parmenides that way, and has so struck many other philosophers

2 John Mansley Robinson, An Introduction to Early Greek Philosophy (Boston: Houghton Mifflin, I968), II5 (Diels-Kranz 28 B 8). 
since his time, resulting in the incorporation of at least parts of his conception in their own theories. My hypothesis concerning Parmenides' aesthetic motivation may receive at least partial confirmation from his choice of a literary vehicle in which to convey his theory; it takes the form of a poem, written in hexameters, in which he recounts his instruction by a goddess in the Way of true thinking. Even if Parmenides was not an especially gifted poet, this choice of a vehicle says something about where he perceived the appeal of his theory to lie. This correspondence between the aesthetic motivations internal to a metaphysical theory and the means chosen for its communication is a theme that will recur throughout our story.

Parmenides' bête noir, Heraclitus, put forward a theory with a very different sort of aesthetic appeal. Heraclitus' view of the world is almost literally kaleidoscopic. The world consists of continuous flux and neverending transformations, held in balance by the tension of opposites, and symbolized by that most mobile of the "elements," fire:

This world-order, the same for all, no god made or any man, but it always was and is and will be an ever-living fire, kindling by measure and going out by measure...

All things are an exchange for fire, and fire for all things; as goods are for gold, and gold for goods. ${ }^{3}$

The aesthetic element is evident when Heraclitus writes,

To god all things are beautiful and good and just, but men suppose some things to be just and others unjust. ${ }^{4}$

Here as with Parmenides, the aesthetic appeal of the view is reflected in that of its presentation; Heraclitus was undoubtedly more successful as an aphorist than Parmenides was as a poet.

Plato, of course, is an inescapable part of the story we are telling; indeed, this essay reveals itself as one more of those innumerable "footnotes on Plato." For Plato, the case I am making scarcely requires argument; it

\footnotetext{
3 Robinson, An Introduction to Early Greek Philosophy, 90, 9I (Diehls-Kranz 22 B 30).

${ }^{4}$ Ibid., 92 (Diehls-Kranz 22 B IO2).
} 
suffices to cite a familiar passage from Socrates' speech (ostensibly quoted from Diotima) in the Symposium:

The person who has been instructed thus far about the activities of Love, who studies beautiful things correctly and in their proper order, and who then comes to the final stage of the activities of love, will suddenly see something astonishing that is beautiful in its nature. This, Socrates, is the purpose of all the earlier effort.

In the first place, it is eternal; it neither comes into being nor passes away, neither increases nor diminishes. Therefore, it is not beautiful in one respect while ugly in another, nor beautiful at one time while ugly at another, nor beautiful with reference to one thing while ugly with reference to something else, nor beautiful here while ugly there, as though it were beautiful to some while ugly to others. Moreover, the beautiful will not appear to this person to be something like a face or a pair of hands or any other part of the body, nor will it appear as a particular statement or a particular bit of knowledge, nor will it appear to exist somewhere in something other than itself, such as in an animal, in the earth, in the sky, or in anything else. On the contrary, it exists as itself in accordance with itself, eternal and uniform. All other beautiful things partake of it in such a way that, although they come into being and pass away, it does not, nor does it become any greater or any less, nor is it affected in any way. When someone moves through these various stages ... and begins to see this beauty, he has nearly reached the end. ${ }^{5}$

Once again, beauty in the metaphysical conception is matched by beauty in its presentation; I think there will be little argument that Plato's dialogues are the single most outstanding literary creation in the entire history of philosophy.

There is no doubt that similar motivation appears in Plato's follower Plotinus, in spite of his paradoxical insistence that the One is not beautiful, but rather "beyond beauty":

[The soul] must, I say, withdraw from understanding and its objects and from every other thing, even the vision of beauty. For everything beautiful comes

5 Plato, Symposium, 210e-2rrb, in The Symposium and The Phaedrus, Plato's Erotic Dialogues, translated with introduction and commentaries by William S. Cobb (Albany: SUNY Press, 1993), 48. 
after it and is derived from it, as all daylight from the sun. It is for this reason that Plato says that the One is ineffable in spoken or written word. ${ }^{6}$

In this connection we may recall the remark of A. H. Armstrong that Plotinus "very often represents the One-Good as That to which no predicates and no determinations can be applied because It is more and better than the reality of which It is the source, and Its excellence goes beyond the resources of our thought and language." Surely the phrase in the quotation, "even the vision of beauty," is significant, indicating that somehow this vision is closer than anything else to the truth about the inexpressible One, even while it necessarily falls short of that truth.

It would be easy to go on drawing out similar thoughts from the great medievals, all of whom were profoundly influenced, directly and indirectly, by Plato and Plotinus. Life is short, however, and so must philosophy be, if it hopes to have a living audience! So we skip forward some fifteen centuries, and take as our next example Leibniz. Leibniz' thought is rich and complex, but it would be difficult to deny that aesthetic motivations play an important role in it. He may well have agreed with sentiments of the sort we have seen in Plato and Plotinus; my point here, however, concerns rather the aesthetic appeal Leibniz found in the system of monads that was the core of his metaphysic. He held that "each possible [universe] has a right to claim existence in proportion to the perfection it involves." Furthermore, "perfection" is defined in terms that carry strong aesthetic overtones: the system of monads "is the means of obtaining the greatest possible variety, together with the greatest possible order: in other words, it is the means of obtaining as much perfection as possible." Pierre Bayle, Leibniz states, "was inclined to believe that I attributed to God too much, and even more than is possible. But he was unable to adduce any reason why this universal harmony, due to which every substance exactly expresses all the others through the relations it has with them,

${ }^{6}$ Plotinus, Enneads, VI. 9, in Source Book in Ancient Philosophy, Revised Edition, ed. Charles M. Bakewell (New York: Charles Scribner's Sons, I939), 397-398.

7 A.H.Armstrong, An Introduction to Ancient Philosophy, $3^{\text {rd }}$ Edition (Boston: Beacon Press, I963), I8r. Note also Armstrong's comment that "Not infrequently, in spite of his carelessness about style ... the power of his thought forces him to a great magnificence of expression" (Ibid., p. I76). 
should be impossible." Admiring his own theory, Leibniz exclaims, "Thus there is nothing uncultured, sterile, or dead in the universe, no chaos, no disorder, though this may be what appears. It would be about the same with a pond seen from a distance: you would perceive a confused movement, a squirming of fishes, if I may say so, without discerning the single fish." I do not claim that aesthetic reasons were the only reasons Leibniz had for embracing this theory, but there can be no doubt that they were for him important reasons.

Skipping forward another two centuries, we come to a philosopher who may well be the most outstanding metaphysician of the twentieth century-Alfred North Whitehead. Like Leibniz, Whitehead crafted a rich and complex metaphysical system, and here also one could hardly deny that aesthetic considerations play a major role. He did not, it would seem, view God as himself the supreme instance of beauty, so much as the instigator of both order and novelty in the world, with the aim of bringing the world-system into a condition of great intrinsic beauty and harmony. In setting up the Cosmological Problem - the problem which is to be resolved by a proper understanding of the role of God-Whitehead develops two pairs of polar opposites: permanence/flux, and order/novelty. Both these contrasts, I submit, are essentially aesthetic in nature, and they set the tone for what follows concerning God: ethical considerations, while not without relevance, are in a manner submerged and subordinated to the aesthetic goal. The final resolution of these opposites, furthermore, is established through the harmonization of the struggles and the triumphs of finite beings in the consequent nature of God:

The wisdom of subjective aim prehends every actuality for what it can be in such a perfected system - its sufferings, its sorrows, its failures, its triumphs, its immediacies of joy — woven by rightness of feeling into the harmony of the universal feeling ... The revolts of destructive evil, purely self-regarding, are dismissed into their triviality of merely individual facts; and yet the good they did achieve in individual joy, in individual sorrow, in the introduction of needed contrast, is yet saved by its relation to the completed whole. The image ... under which this operative growth of God's nature is best conceived,

8 W. G.von Leibniz, Monadology 54, 58, 59, 69. In Monadology and Other Philosophical Essays, translated and edited by Paul Schrecker and Anne Martin Schrecker (Indianapolis: Library of Liberal Arts, 1965), I56, I57, 159. 
is that of a tender care that nothing be lost.... He does not create the world, he saves it; or, more accurately, he is the poet of the world, with tender patience leading it by his vision of truth, beauty, and goodness."

God as "the poet of the world"-with that one phrase, Whitehead himself makes my case, and I have no need to say more.

My final example is none other than Ludwig Wittgenstein- not the Wittgenstein of the Investigations, who as we all know was no metaphysician, but rather the early Wittgenstein of the Tractatus. In the Tractatus, I acknowledge, the aesthetic element is somewhat more subtle than with our other examples, yet I think it is both present and important. The overall effect is perhaps similar to that of a geometric abstraction-but geometric abstractions can have their own kind of beauty; think of the paintings of Mondrian. Beyond this, I submit that a further aesthetic element is contributed by the paradoxes integral to Wittgenstein's enterprise, paradoxes that create a sense of mystery with a powerful aesthetic appeal, something like a philosophical version of an Escher engraving. One major paradox is found in the statement of a metaphysical view which includes the assertion that metaphysical views cannot be stated; this is the ladder we must throw away after we have climbed up it. There is also the paradox of what he termed the "second part," of his work, the ethical part which Wittgenstein did not write but which is nevertheless, according to him, the most important part of his philosophical work $!^{10}$ Furthermore, considerable artistic skill is expressed in the literary form of the Tractatus, including such unforgettable aphorisms as "The solution of the problem of life is seen in the vanishing of the problem." ${ }^{11}$ There are also the wonderful, hymn-like rhythms of the opening sentences of the work. I've often thought one could almost get away with reading these sentences as one of the lessons in a church service. People wouldn't understand them,

9 Alfred North Whitehead, Process and Reality: An Essay in Cosmology, Corrected Edition edited by David Ray Griffin and Donald W. Sherburne (New York: The Free Press, I978), 346.

${ }^{10}$ See his letter to Ludwig von Ficker, in Brian McGuinness, Wittgenstein: A Life: Young Ludwig I889-I92I (Berkeley: The University of California Press, I988), 288.

${ }^{11}$ Ludwig Wittgenstein, Tractatus Logico-Philosophicus, German text with translation by D.F.Pears and B.F. McGuinness (London: Routledge and Kegan Paul, I963), 6.521, p. I49. 
of course, but the sound and cadence seem just about right for such an occasion:

The world is all that is the case.

The world is the totality of facts, not of things.

The world is determined by the facts, and by their being all the facts.

For the totality of facts determines what is the case, and also whatever is not the case.

The facts in logical space are the world. ${ }^{12}$

I submit that these aesthetic features of the Tractatus go quite a long way in accounting for the continuing fascination of this work for many philosophers.

It is my hope that I have persuaded you of my general claim, that beauty has been and remains an important element in the creation and reception of metaphysical views. But what shall we make of this fact? What, if anything, is its broader significance? Our erstwhile friends, the logical positivists, would have been ready with a response. Beauty and other "emotive" considerations are not merely important for the practice of metaphysics; they constitute the only content of metaphysical theories, which are simply misunderstood if they are viewed as having any cognitive significance. It follows from this that, if we do not follow Hume's recommendation to consign the works of metaphysics to the flames, we should at least turn them over to the literary critics for appropriate disposal.

But of course, hardly anyone thinks this way any more. A response more typical of contemporary philosophers would be that the aesthetic properties of metaphysical theories, while perhaps important for effective presentation. are simply irrelevant to whatever cognitive value these theories may possess. Believing a theory because it is beautiful is akin to believing there are fish in the pond because we should like to catch some for our dinner. This may seem a natural and initially plausible response, but examined more closely it faces serious difficulties. One such difficulty is that of accounting for the role of aesthetic values in the assessment of scientific theories, which are frequently taken as a model of the right kind of hard-headed rationality. It is said that Albert Einstein slept peacefully through the first serious test of his general

${ }^{12}$ Wittgenstein, Tractatus Logico-Philosophicus, I-I.I3, p. 7 . 
theory of relativity, involving the deflection of light from a distant star by the gravitational attraction of the sun during a solar eclipse. He later told his friend Max Planck, who spent a sleepless night awaiting the results, that he need not have worried; a theory as beautiful as this one could not have failed to be confirmed $!^{13}$ In a similar vein Thomas Nagel, reflecting on some of C. S. Peirce's thoughts about science, remarks that "the idea of a natural sympathy between the deepest truths of nature and the deepest layers of the human mind, which can be exploited to allow gradual development of a truer and truer conception of reality, makes us more at home in the universe than is secularly comfortable." ${ }^{14}$ Nagel nevertheless finds the idea of such a "natural sympathy" compelling, and tries to console his naturalistically-minded friends with the thought that "one can admit such an enrichment of the fundamental elements of the natural order without going over to anything that should count literally as religious belief." 15

The denial of the cognitive relevance of beauty is not merely in conflict with scientific practice; it is also question-begging. To be sure, if we knew at the outset that human life and human minds are the accidental byproducts of purposeless forces that have operated without thought for them or anything else-if we knew this, then it might be reasonable to conclude that the human sense of beauty is without cognitive significance. But of course, we do not know this; on the contrary, whether or not this naturalistic hypothesis is correct is precisely one of the questions that metaphysical inquiry needs to address. If, then, we wish to proceed in a way that leaves it open whether this, or some more human-friendly view of the universe, is correct, we should also leave it open that our awareness of beauty is to some degree a pointer to the truth of things. Not every beautiful theory can be true-Einstein went too far there, if indeed he was wholly serious in his remark to Planck-but perhaps beauty is, in some degree, an indication of the cognitive value, the truth-likeness if you will, of our theories of the world. This is the possibility that will be explored in the remainder of this paper.

${ }^{13}$ Karl W. Giberson, “The Patent Clerk from Mount Olympus," Books and Culture, November/December 2005: 37 .

14 Thomas Nagel, The Last Word (New York: Oxford University Press, 1997), I30 (emphasis in original).

${ }_{15}$ Nagel, The Last Word, 132. 
Suppose, then, that we assume provisionally that the aesthetic value of a metaphysical view counts to some degree in favor of its truth. Can we go further, and say which particular aesthetic qualities are most relevant? This is an extremely difficult question. We should not succumb to complete aesthetic relativism, but it cannot be denied that human beings exhibit a wide range of variability in their aesthetic responses. This variability, furthermore, will almost certainly prove to be relevant to the question of which metaphysical theory is most aesthetically satisfying. (Recall Quine's preference for desert landscapes!) The challenge, then, is to put forward aesthetic criteria with some determinate content, without simply engaging in special pleading for one's own preferred metaphysical conclusions. As with other journeys between Scylla and Charybdis, there is a considerable likelihood of shipwreck, but one can only do one's best. I have three criteria to suggest.

First, an aesthetically satisfying metaphysic must exhibit convincingly both the multiplicity in the world and its underlying unity. This of course is the old standard, "variety in unity," which is axiomatic for aesthetic analysis. The criterion is recognized explicitly in Leibniz' combination of the "greatest possible variety" with the "greatest possible order," and in Whitehead's polarity of order and novelty. Sheer unresolved diversity lacks cohesion and suggests a mere catalog of contents, but unrelieved unity becomes sterile and empty; neither is aesthetically satisfying. Parmenides pretty clearly fails if judged by this criterion; Heraclitus may also be in trouble, though this is less clear. For Plato the problem of "the one and the many" becomes a central theme for philosophical reflection, and it has remained so ever since.

My second criterion is somewhat less obvious. I propose that an aesthetically compelling metaphysic must give a central role to the values pertaining to living creatures and especially to persons. The reason this is not so obvious is that there are numerous aesthetic values that are formal in nature and that, like "variety in unity," do not pertain in any special way to living creatures or to persons (except, of course, that it takes living beings to appreciate them). Nevertheless, I maintain that the values peculiar to life and to personality occupy a privileged place in our aesthetic responses, and that a metaphysic that fails to honor this will prove to be aesthetically unsatisfying. As evidence, I point to the fact that by far the preponderance of the greatest works of art feature these values, by way of representing 
human beings, or animals, or sometimes supernatural beings in humanlike or animal-like guises. This holds true from the Winged Victory and the marbles of the Parthenon to the drawings of Leonardo and Rembrandt and the paintings of Renoir and Picasso. There are numerous exceptions, of course. But even landscapes devoid of human and animal figures tend to include features that signal to us the human relevance of what is portrayed. The Chinese mountain-scape has a scholar's pavilion or a hermit's hut; Monet's water lilies are found in a garden tended by human hands and intended for human enjoyment.

One could object that this fact about our aesthetic preferences merely reflects our narcissistic human self-preoccupation, and has no wider importance. But to adopt that stance would be to revert to a position we have already examined and found to be question-begging: that the existence of human persons and the things they value is merely accidental, and has no significance for the nature of things in general. Our present stance, in contrast, is one in which we take seriously the aesthetic values humans do in fact appreciate, and consider where they may point if taken as a clue concerning the truth of things.

Nevertheless, the pre-eminence suggested here for the values of life and personality comes into serious conflict with trends in contemporary metaphysics, especially with reductive versions of materialism and naturalism. Whitehead formulated the "fallacy of misplaced concreteness" in order to protest the tendency to take the abstractions of theoretical physics as representing ultimate reality. His own philosophy, significantly termed by him the "philosophy of organism," was designed in part as a corrective to this tendency. Even those of us who are unable to embrace his philosophy in its details may well consider his objection here to be well-founded.

My third and final point is perhaps not aptly termed a criterion; I put it forward, not as a requirement for a metaphysic that will be aesthetically satisfying, but rather as a desideratum. My proposal is that a metaphysic that affords the greatest possible aesthetic satisfaction will be one in which the ultimate reality is also the supreme object of aesthetic contemplation. This is what Parmenides, and Plato, and Plotinus were seeking, and believed themselves to have found; it also captures a central feature of the thought of Anselm, Spinoza, Jonathan Edwards, and many others before and since. Clearly, this represents the maximum demand that aesthetics can make 
upon metaphysics, and some will find that it exceeds what can reasonably be asked. To be sure, for the promise of this approach to be realized more is needed than the mere postulation of an ultimate Beauty which is also the final Real. The existence of such an entity must be made vivid to the metaphysical imagination, and this will almost certainly call (among other things) for a fuller and more definite account of its properties. (This by the way points to a difficulty for the more severe forms of negative theology, for example as practiced by Gordon Kaufmann and John Hick. One cannot readily get enough of a grasp on a Real characterized only in negative terms, to feel very joyous or worshipful about it.) Many will revert here to our second criterion, and will insist that the ultimate Beauty must possess many of the attributes of personality, no doubt understood in some analogical fashion. Parmenides and Spinoza will demur, and their objections must be duly considered. Nor is it my contention that questions such as these can be settled on aesthetic grounds alone. My aim has been to gain for aesthetics a place in the metaphysical conversation, not to turn metaphysics into an aesthetic monologue. So there is still need for all of the arguments and counter-arguments, as well as testimonies of experience and claims about proper basicality. Suppose, however, that all of this has been done-all the arguments carefully formulated and evaluated, all of the testimonies given their due weight, all the objections heard and considered. If, when all that has been done, we are able to arrive at a warranted belief in an aesthetic Object of the sort here described-then at last, we shall have found the Truth that is Beauty, the Beauty that is Truth. 